\title{
THE IMPORTANCE OF 'SIGNIFICANT OTHERS' IN BRIDGING THE GAPS BETWEEN DIFFERENT READING CONTEXTS
}

\author{
Anna-Karin Svensson \\ Malmö University, Sweden \\ E-mail: anna-karin.svensson@mau.se
}

\begin{abstract}
The current research is an in-depth study of four pre-service teachers' own experience of reading in various contexts and for different reasons. The aim is to analyse what has been significant regarding reading in a life history perspective by the use of narratives. A socio-cultural perspective on reading is used as analysis tool. The over-arching result from analysing pre-service teachers' narratives is that reading is a relational process regardless of the context reading takes place in. The emerging themes allow a deeper understanding on critical aspects for developing reading in various contexts and at different levels. Significant others seem important in every reading practice, from new readers in primary school to pre-service teachers' reading at university level. The narratives reveal a need for bridging the gaps that arise between the reading practices in the various contexts that students meet in school and university. Key words: pre-service teachers' narratives, reading contexts, reading trajectories, significant others.
\end{abstract}

\section{Introduction}

Three years after finishing upper secondary school over 40 per cent of the students in Sweden have started studying at college and university (SCB, Statistics Sweden, 2016). This indicates that college and university have a broad recruitment with the purpose to create diversity and reduce social unbalance in school and society, and thus attract students from non-study environments and/or with other cultural and linguistic background to apply for higher education (University and Higher Education Council, 2014). The teacher education in particular has developed into an education where students are recruited largely from environments lacking academic traditions. The teacher education invites students with varying linguistic and cultural backgrounds, known as widening participation, which is important for creating a multicultural school and society (Leathwood \& O'Connell, 2003; Leese, 2010). In practice, however, it becomes complicated if the instruction is designed for a homogeneous group of students, while the students actually represent a heterogeneous group. Therefore, new demands on how the training should be designed to meet the students' needs are required. At the same time, the theoretical academic requirements have increased, and the students are left to independent work, where a large amount of literature is a part of the education (Biggs, 2011). Haggis (2006) uses the concept 'new student', a student who spends most of the time on self-studies and only shorter periods on campus and then mostly at taught sessions (Leese, 2010 p. 241). In order to be able to study and read a large amount of literature on their own, good reading skills and an ability to orientate themselves to different text practices are required. In previous research in Sweden Ask (2005, 2007), Blåsjö (2004) and Bergman (2016), studied students' encounter with the written language in academic context. The studies demonstrate the problems students experience at transitions from high school to college and university, revealing students' difficulties in meeting the new demands in the academic literacy practice. 
Anna-Karin SVENSSON. The importance of 'significant others' in bridging the gaps between different reading contexts

\section{PROBLEMS \\ OF EDUCATION \\ IN THE $21^{\text {st }}$ CENTURY Vol. 76, No. 2, 2018 \\ 232}

a teacher education view it is of great interest to study what pre-service teachers bring into the teacher education concerning reading, and what experiences and perceptions they bring from early reading in life to the encounter with teacher education.

\section{Problem of Research}

Experiences from language workshops at the teacher education revealed large differences in the pre-service teachers' reading development, when they were confronted with the academic literacy context. In order to get a deeper understanding of the aspects that are of importance to explain development of reading in various contexts in a life perspective, pre-service teachers' narratives were collected and analysed.

The following two research questions were asked:

- Which aspects on reading are expressed as significant in the pre-service teachers' narratives from early childhood until entering teacher education?

- Which aspects on reading are expressed as significant in the pre-service teachers' narratives during their teacher training?

The current research is based on results previously presented in a dissertation written in Swedish (Svensson, 2011), where four pre-service teachers' experiences of their own reading in various contexts and for different reasons were assessed.

\section{Research Focus}

To place the present research in a wider context, a socio-cultural perspective on reading is used, as means to shed light on empirical material (Svensson, 2011), and to provide a relevant matrix of interpretation. A socio-cultural perspective on reading takes its points of departure that reading occurs together with others, in situated practices (Gee, 2015; Lemke, 1990, 1995; Street, 2014). Here reading is primarily seen as a social and creative process of creating meaning. This process involves interpretation, drawing conclusions, making associations, linking to own experience, as well as to other texts and the surrounding world.

In the past few years, research within a socio-cultural perspective have dealt with the issue of how the significance and function of language use varies between different social and societal contexts. Researchers such as Gee, (2015) Lemke, $(1990,1995)$ and Street (2014) use the concept of literacy for language-writing activities and embrace an ideological approach where literacy is regarded as a complex social phenomenon related to social and political processes. Literacy here means to be able to use different kinds of texts in different contexts and to be able to review critically, that is, to question the contexts and purposes for which texts are written and intended to be used. Literacy also means that you independently manage, communicate and use the languages required in different contexts.

In their research on academic literacy, Lea and Street (2006) present a model based on the NLS (New Literacy Studies). They problematize the view of academic reading and writing by pointing at three approaches that overlap, 'study skills', 'academic socialization' and 'academic literacies' (Lea \& Street, 2006, pp. 368-377). The three approaches have a lot in common, but the first two are the ones that have dominated the current view of knowledge from elementary school to college and university. The latter approach is associated with meaning, identity and power. Academic literacy, i.e. ability to use effectively conversation, listening, reading and writing as dynamic complex forms of knowledge, may be interpreted as a tool to assimilate knowledge in an academic context. However, to enable NLS practice of learning, the student must experience participation in the new educational contexts (Lea and Street (2006)). For this to happen the students' background is utilized while they are socialized into new contexts and are challenged in new ways of learning to be active co-creators in various knowledge 
processes. Such an approach of learning can obviously cover learning at all levels of education, from preschool to college and university. These learning environments can be compared to 'participation in social communities' (Lave \& Wenger, 1991).

Lave and Wenger (1991) see participation in social communities as the basis for learning together with others in various contexts, so-called 'legitimate peripheral participation'. Lave and Wenger use notions such as 'situated learning in various practices' where the student develops from novice to expert. According to this reasoning, participation is required to achieve various appropriate literacy competences, in particular social contexts from which texts emanate. In these social contexts, a supportive guiding educator could have an impact on, how the child/ pupil is incorporated into the group, and becoming the novice who progressively develops, learns, and appropriates the competences, which are demanded (Wenger, 1998; Vygotsky, 1978, 2012).

'Community of practice' (CoP), which has been developed in practical professional communities includes, e.g., tailors, midwives and butchers. This leads to the question if the CoP can be applied also to learning in knowledge environments. It could be discussed if Wenger's definition of CoP (1998) as mutual engagement in a joint enterprise with a shared repertoire can be transferable into a knowledge environment, where individuals can develop and learn for different purposes and aims in a theoretical context. This is what Arthur (2016) problematizes in his research on using $\mathrm{CoP}$ in the university environment. Arthurs' findings indicate that the interactions within CoP's varied depending on the participants' skills, experiences and qualifications. If for example newcomers' expertise is higher than old-timers in a certain discipline, there will be challenges for academic developers.

Zepke and Leach (2007) were interested in how students from different cultural backgrounds in New Zealand adapt to the university context. They investigated what was necessary for students to remain in and being integrated in or adapted to the new educational context. According to Zepke and Leach $(2007,2010)$ the concept of integration means that students will be integrated into the prevailing culture, where the students learn existing institutional and pedagogic norms, values and practices, with the result that he/she will be incorporated into the new community. Adaptation, according to Zepke and Leach (2007, 2010), means that the students add new competences to the already existing, and use and customize the competences as required in the situation. They conclude that in order to meet students from different cultural backgrounds and to encourage them to continue and succeed in education, it is essential to create a learning environment that promotes international, social and cultural diversity. They further stress the importance of showing respect for diverse talents and ways of learning and understand the importance of contextual meaning. It is necessary to adapt the teaching to the various student groups even in higher education.

Van Enk, Dagenais and Toohey (2005) discuss the school's literacy practice and point out that 'the emphasis in research on literacy in formal educational settings has been on some neutral tool with universal applications' (p. 508). This relates to Wertsch (1998), who stressed that studies of literacy learning must focus on mediated actions, mediated tools and how the students can use literacy competence learned in a school context. The education system does not offer the same conditions and opportunities for learning to all students, and this has an impact on students' abilities to do well in school-based literacy tasks. Gee, (2015) consider that it is impossible to ignore the fact that there is a power aspect on what students in school are expected to read and learn. Gee (2015) emphasizes that literacy teaching also has a content of something. This 'something' is always a text of a certain type, in a certain genre and requires scaffolder socialization into the social practices where the text will be read and used, which is of interest and motivation for the student. Literacy 'in singular', according to van Enk, Dagenais and Toohey (2005), is to refer to for example 'good language and literacy skills' (p.508) without indicating where or by whom or for what purposes the skills in question are considered 'good'.

The child's development in becoming a reader can be viewed as an essentially cultural phenomenon. If the child is considered as a reader and receives attention as such, he/she will 
Anna-Karin SVENSSON. The importance of 'significant others' in bridging the gaps between different reading contexts

PROBLEMS

OF EDUCATION

IN THE $21^{\text {st }}$ CENTURY Vol. 76, No. 2, 2018

234

feel included in the 'literacy club' (Smith, 2012 p. 229). This is a crucial part in the child's reading development. Smith argues that to become a member of the 'literacy club', all that is needed is the mutual recognition by the group that uses the written language. Motivation springs from the individuals that the child meets in his/her surroundings, who are engaged in practices pertaining to the written language. Brooks (2007) studied the hypothesis if teachers must be confident and avid readers and writers to be effective reading and writing teachers. $\mathrm{He}$ used a case study with four fourth-grade reading and writing teachers, who were nominated as exemplary reading and writing teachers. Brooks (2007) claims that teachers' reading and writing competence and experience play a role in their teaching, partly contradictory to what the teachers in the study, who pointed out the importance of knowing to support their students as readers and writers instead of showcasing their own reading and writing in the classroom.

Researchers, such as Cochran-Smith (1994), Dyson (1997) and Heath (1983) emphasize the child's socialization into various text worlds, together with parents, peers and educators. A useful metaphor for children's socialization into reading may be the concept of 'literary breastfeeding' as Crafoord (1991, p.26) uses as a metaphor in his tale Daddy's body. For a child to become motivated in written language practices, it is necessary that the environment show how to relate to these practices and that the environment is interested in the literacy experiences the child brings to school (Heath, 1983, 2001; Heath \& Street, 2008).

Applegate and Applegate (2004) question if prospective teachers who do not read themselves can teach their students to become dedicated and engaged readers. They described this view as 'the Peter Effect' (p.556). In a New Testament story, the apostle Peter responds to a beggar who asks him for money that he 'cannot give what he does not have' (Acts 3:5). Using 'The Literacy Habits Questionnaire' in a survey including nearly 400 elementary education majors they found that less than half of them could be classified as enthusiastic readers (Applegate \& Applegate, 2004). Nathanson, Pruslow and Levit (2008) used the same questionnaire in a survey of 747 students in a graduate school of education, who were studying to become special education and/or regular education teachers. The result from the survey showed that 47 per cent of the students characterized themselves as enthusiastic readers and 17 per cent indicated that they had little or no pleasure in reading. It was revealed that the unenthusiastic readers did not have teachers who shared a love of reading, whereas the enthusiastic readers did have such teachers. Nathanson, Pruslow and Levit (2008) discuss how teachers make a difference in students' development of literacy and suggest that teacher-training curricula must include the 'science' of literacy (p.319). They point out that college courses should emphasize the importance of motivating readers just not only for the intellectual competencies of the students but also for their hearts (Nathanson, Pruslow, \& Levit, 2008). Finally, they suggest that one way to break 'the Peter Effect' (Applegate \& Applegate, 2004) is to make illiteracy an open topic for discussion in schools and universities. Teachers in school as well as professors in university must raise consciousness about illiteracy and disinterest in reading. In a later study by Applegate et.al (2014) involving more than 1000 students, they confirmed the persistence of 'The Peter Effect', showing that nearly 50 per cent of the students lacked reading enthusiasm. They concluded that teacher educators must address the importance of enthusiasm for reading if teachers should be able to create positive impacts on their future students.

Benevides and Stagg Peterson (2010) concluded in their study of 227 pre-service teachers that positive attitudes, regular reading habits and recollection of early literacy experiences cannot be assumed qualities. They claim that teacher education programs should not ignore the discrepancies in the pre-service teachers' reading abilities. Researchers as Hall (2005), Warren-Kring and Warren (2013) have investigated teachers and student teachers' attitudes and perceptions about reading strategies regarding reading in content areas. Hall (2005) discusses reasons that motivate pre- and in-service content area teachers' attitudes and beliefs in teaching or not teaching reading to their students. Hall (2005) found that simply creating positive attitudes towards teaching reading was not enough. The pre-service and in-service teachers need to know how to teach reading in a way that' is both specific to the subject and to the students being taught' 
(Hall, 2005, p. 412). Warren-Kring and Warren (2013) measured the students' attitudes towards implementing literacy strategies within the content area classroom. The students were taught hands-on literacy strategies in four content areas (English, science, history and mathematics) and the findings showed significant gains pre to post on the attitude scale.

Leland (2013) studied 106 pre-service teachers in teacher education programs of teaching and learning based on their various experiences at school and home. Data includes narratives from an open-ended survey questionnaire. The study focused on the pre-service teachers' preparation of teaching emergent literacy from a teacher preparation course as well as field experiences from school. The result showed a positive impact on most of the participants' perceptions of teaching emergent literacy. The participants also compared their own literacy histories and the impact of learning from their clinical instructor and applying strategies in the field classroom. Leland (2013) stressed that the teacher education programs must be more explicit to help pre-service teachers to understand changes occurring in today's classrooms. Pre-service teachers' literacy histories are likely to act in contradiction to the aims of education. Leland refers to Zeichner (1996) who points out the importance of teacher education programs focusing on pre-service teachers' ability to analyse and evaluate their personal stories of teaching and learning. They emphasized that children's learning can be affected if effective teaching is not implemented (Leland, 2008). Toll, Nierstheimer, Lenski and Kolloff (2004) used a nontraditional research approach when they used their own stories about teaching. The result shows that there are conflicts between the education and beliefs in university and the 'real world'. The researchers conclude that to shape their work with pre-service teachers they have to face education as a complex activity and they have 'to make struggles, visible and essential' (p. 175).

\section{Methodology of Research}

\section{General Background}

The methodology chosen is based on an epistemological approach where the life story is viewed as something that can provide knowledge about people's experience and perceptions. These individual stories can also improve knowledge about a larger narrative, which is about the culture, history and the society that surround the narrators (Goodson \& Sikes, 2001). Through people's personal stories, a picture of the life history they inhabit is traced, which can be related to the social and cultural surroundings (Brockmeier \& Carbaugh, 2001; Bruner, 1990, 2001). In this way, when the individual narrative is contextualized, it may create knowledge about historical and social conditions.

The present research was performed during second half of 2005 and the first half of 2006. The empirical material should be seen as examples of experiences from the pre-service teachers presented. It is only through transparency in the presentation of study purpose; selection of participants, data processing and analysis, the reader will be acquainted with the researcher's procedures throughout the study. The study could however be considered valid because it reveals what has been the intention, i.e., exploring some pre-service teachers' narratives from experiences of reading in a life perspective. Reliability is based on the ethical starting points in the meeting with the students, which creates trust and opportunity to negotiate the stories. Critical issues in the data processing are how data is processed and what is reduced in the process of interpretation. It is important, as a researcher, to be reflexive, i.e., to be aware of that a narrative is a common construction between the narrator and the researcher, which is not the same as objective truth.

\section{Sample}

The work started with a pilot interview with conversations regarding reading in a life perspective, in order to explore the applicability of the research questions on the students' narratives. Then a survey was constructed to provide the basis for subject selection. The 
Anna-Karin SVENSSON. The importance of 'significant others' in bridging the gaps between different reading contexts

\begin{abstract}
PROBLEMS
OF EDUCATION

IN THE $21^{\text {st }}$ CENTURY Vol. 76, No. 2, 2018

236 questionnaire was sent to 68 pre-service teachers who were recently admitted students, specializing on preschool and the first years of compulsory school. The students were asked to write a short story about their views on reading based on four themes: early memories, important experiences, events and people, favourite books and expectations on reading in teacher education. Although an extra reminder was sent out to all participants in the survey, only twelve responded. The 12 students met with the interviewer for a conversation about the student's memories of reading. This first meeting led to a construction of data for narratives about reading in a life perspective. Each conversation lasted approximately one and a half hours. The conversations were initiated with the open question: Tell me about your memories of reading, from the very earliest, and up to how you experience reading today. The conversations were interpreted, followed by a selection from the group of twelve students.
\end{abstract}

\title{
Procedures
}

In the next step four students were chosen for deeper interview processes. They were all females and were given the fictive names Miriam, Anne, Kate and Eve. The selection was made in order to achieve variation in age and social background, combined with the student's own motivation and ability to verbally talk about personal thoughts, experiences and meetings relating to reading in a life perspective. The four selected students were all females because all the twelve students interested to participate were females. Two students were born in the 1960's (Kate and Eve) and two students were born in the 1980's (Miriam and Anne), which was an interesting aspect from a variety of aspects concerning their age and schooling. The stories could possibly reveal differences in pedagogical and didactic approaches on reading in Swedish primary school in the 1970's and 1990's. This could have significant influence on the stories told, with respect to contextual aspects. Each meeting with the student is based on ethical considerations (2002), were openness and possibility for the student to take part in the conversations in the form of transcripts and printouts during the research process were required. To strengthen the quality of the study, credibility was validated through so-called 'negotiating talks' where the interviewee was given the opportunity to take part in the interpretations of the researcher (Goodson \& Sikes, 2001, Goodson \& Numan, 2003, Lincoln \& Guba, 1985). In the meeting with the students, it is also important to ensure that they feel involved in the various agreements concerning time, content and degree of intimacy in the conversations. Finally, voluntary participation and confidentiality are both basic conditions for the conversation.

\section{Data Analysis}

The data processing of the narratives from early reading until reading in teacher education has been conducted in seven steps: 1) questionnaire; 2) conversation; 3) transcription; 4) written narrative 5) negotiating talk; 6) negotiated written narrative; 7) analysis and interpretation of the narrative.

During the students' second semester in teacher education, new individual conversations were performed with the students about their encounter with reading in the context of teacher training. Processing of data from these conversations was conducted in six steps: 1) conversation; 2) transcription; 3) reading and preparing negotiation; 4) negotiating written narrative; 5) analysis and interpretation; 6) analysis and interpretation of the narratives based on previous research.

Using narrative analysis, the narratives have been compiled, integrated and organized into a configuration from the researcher's interpretation. The configuration (Figure 1) is based on what emerges from the narratives as the most important for the students to become readers in different contexts. In this manner, the configuration has become the researcher's account of the story that is told, a so-called 'narrative configuration (Polkinghorne, 1995). Thus, the students' narratives have been reconstructed into a coherent chronological narrative by analysing the 
content of the narrated. The analysis places each narrative into a wider context, which means that the individual's experiences and contexts are linked. The context therefore appears through

PROBLEMS OF EDUCATION IN THE $21^{\text {st }}$ CENTURY Vol. 76, No. 2, 2018 analysis of the individual story. Questions to be answered from the material in the analysis were: What has been important for reading in a life perspective? What are these phenomena and actions? Where do they occur? When do they occur? How do they occur? With whom do they occur? The questions are inspired from Lemke (1990). By analysing the narratives based on these questions it emerged how the students valued continuity and non-continuity in their reading trajectories.

\section{Results of Research}

The overarching result from the pre-service teachers' narratives shows that reading is a 'relational process' (Figure 1), which occurs with 'significant others'. The significant others are found to be parents, siblings, schoolmates, their parents, teachers and life companions. Significant others 'confirm' and 'invite' the individual to read in various contexts. They may be considered as guides, who create supportive structures and they appear in the narratives, both in a positive and a negative sense.

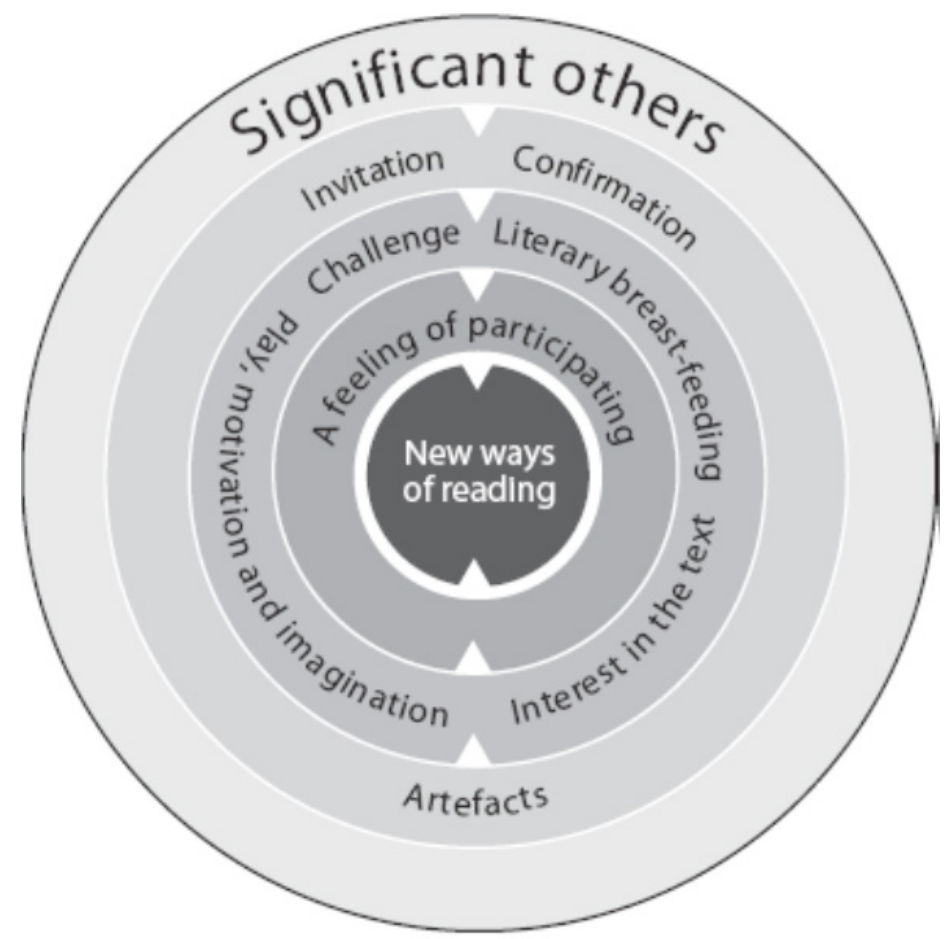

Figure 1: The relational reading process.

The relational reading process leads successively to 'new ways of reading'. To be able to develop 'new ways of reading', certain conditions stand out as particularly significant, in the light of the students' reading trajectories. Important aspects appear to be: being 'invited' and gaining 'confirmation' from 'significant others'; 'artefacts'; 'literary breast-feeding'; 'play, motivation and imagination'; 'interest in the text'; 'challenges' and 'a feeling of participation.' The primary contexts of reading that stand out most clearly in the students' narratives are family, early school years, later school years, secondary school years and teacher education. The relational reading process seems to present a consistent structure, regardless of which context in a life-long perspective, the process takes place in. Figure 2 illustrates the reading trajectory with the contexts recognised in the pre-service teachers' narratives. 
PROBLEMS

OF EDUCATION

IN THE $21^{\text {st }}$ CENTURY

Vol. $76, \frac{2,2018}{238}$

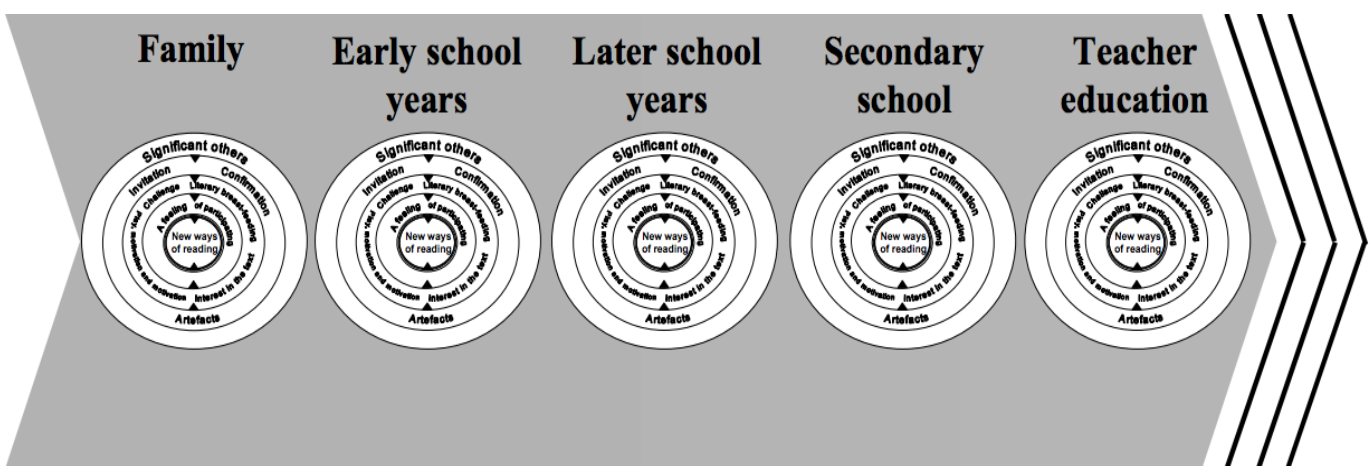

Figure 2: The reading trajectories.

In the pre-service teachers' narratives, it becomes clear that experiences of sharing and participating in a particular reading context are not automatically transferred from one context to another. The pre-service teachers' reading trajectories show that several 'literacy clubs' exist simultaneously in each of the different contexts they describe. In the reading trajectory there are, in addition to the main contexts shown in Figure 2, a variety of sub-contexts where reading occurs, for example in peer groups and leisure centres. These sub-contexts are thus part of either the family context, the school contexts or teacher education context.

At the first meeting with a new context, gaps between contexts are experienced, to a smaller or larger extent.

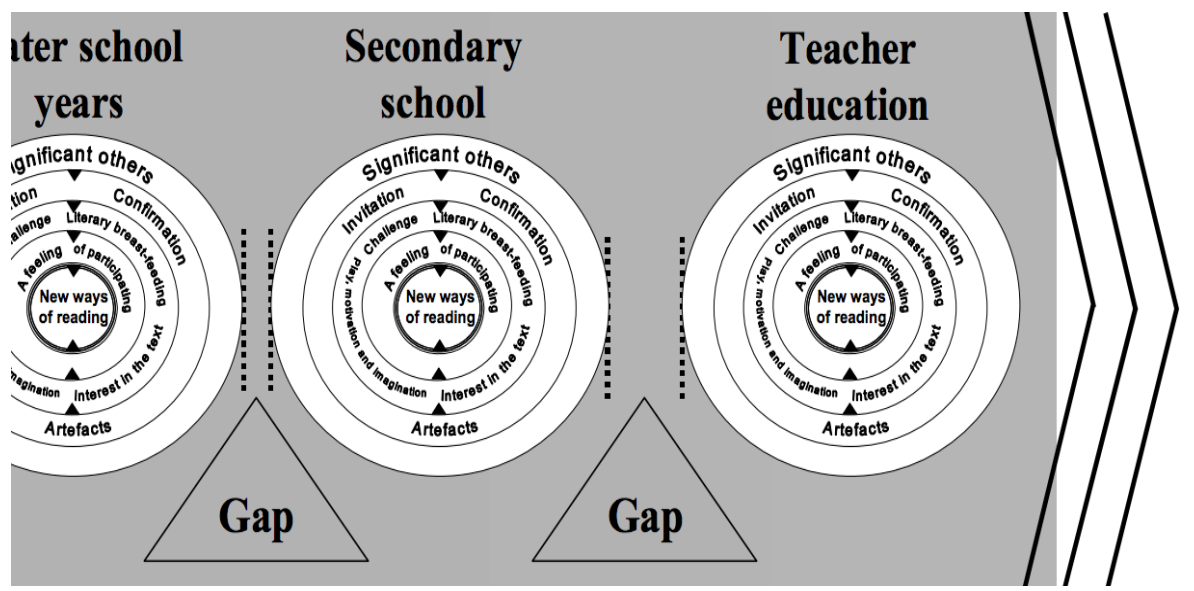

Figure 3: Gaps between different contexts along the reading trajectory.

When the gaps experienced are too large to be bridged, the feeling of personal involvement ceases, and is replaced by feelings of failure, stagnation and exclusion.

\section{Pre-service Students'Reading Trajectories}

Below, the excerpts of some characteristic examples of pre-service teachers' narratives are presented, showing their reading trajectories from early childhood to reading in teacher education. 


\section{Family reading}

Miriam and Anne (both born in the 1980's) talk about how their parents have been reading fiction for them and how this inspired them to start reading themselves.

Miriam says:

And Daddy read a lot to me, a lot of thick books, and so it was a book I learned by heart, though then I was maybe four.

Interviewer:

Do you remember what book it was?

Miriam:

Yes 'Örjan, the eagle fear of flying'.

Interviewer:

Yes.

Miriam:

I knew the story by heart, I didn't know what I read, but I knew when I should turn the page so I, I remember that I followed the reading word by word, but I didn't understand the meaning of it, but it was more like I memorized. But then when I started school, it didn't take long for me to learn to read.

[Miriam, 2005 p.56 authors' translation]

Anne says:

I remember that my parents always read to me. And I have always loved when my parents read to me and it happened regularly. My parents have read to me every night. So, I always had an interest in being read to. Then I wanted to learn to read myself, so I learned to read very early.

[Anne, 2005 p.75 authors' translation]

Kate and Eve (both born in the 1960's) have different experiences from parents' reading. Kate believes that her mother has been reading stories and tales when she was a child, but that the most important person was her sister. Eve says that her parents did not read stories to her, but her sister was very important to her and motivated her in reading.

Eve says:

It was clearly a spur, it absolutely was. And I remember these things that I learned in advance, I read in advance in the reading book. I wanted to catch up with my sister a little bit, I think. I learned a chapter in the book by heart. That I remember.

[Eve, 2005 p.105 authors' translation]

Kate says:

I have an older sister and through her, I remember, it may not have as much to do with books, but she, I loved when she told stories to me! She made up free fantasy. I remember she used a small teddy bear when she made up stories for me. I thought it was great! Then she started school and then I thought it was exciting when she came home telling ... what she had learned. And I had a slate, such a small blackboard which I still have today for my kids, and where I usually write and draw and make the letters and so on.

[Kate, 2005 p.92 authors' translation]

Significant others prove to be both parents and siblings in the family context. They are perceived as inviting and confirming, which gradually leads to a desire to both listen to stories and to initiate own reading. The students talk about various artefacts that appear to have played a role for inspiration to play and reading.

\section{Reading in early school years}

These artefacts are changed in school by primarily the introduction of readers and traditional teaching materials as artefacts for learning to read and conveying knowledge. In the early school years, the students have learned to read chapter books on their own. Literary 
Anna-Karin SVENSSON. The importance of 'significant others' in bridging the gaps between different reading contexts

\begin{tabular}{r|r} 
PROBLEMS \\
OF EDUCATION \\
IN THE 21 ${ }^{\text {st }}$ CENTURY \\
Vol. 76, No. 2, 2018 \\
\hline 240
\end{tabular}

reading occurs both at school and in the family. However, reading literature on your own mostly occurs at home.

Anne says:

I must mention Viveca Sundvalls' novel "The diary of a first grader". It was my first novel that I got through, and then I started the first degree in primary school, that is what I remember. It was simply the best! Just read about Mimmi, I was at the same age then, and she was in first class when I started first class, yes, a lot like that... It was very ... and I just did it myself, I could read and then I read it forever. A hundred times I've read that novel.

Interviewer:

But this was initiated by the teacher at school?

Anne:

No no, I got it from my mother on my birthday.

[Anne, 2005 p.78 authors' translation]

Miriam and Anne describe how they are challenged when meeting reading practices at school, and their interest of reading change. Miriam read a novel in school about a girl who has reading difficulties and how the teacher treats the girl badly in front of the other children. Miriam can see similarities to her own situation in school. She likes the novel a lot and remembers that she identifies herself with the girl in the novel and felt that the teacher did not like her either.

Miriam says:

Yes, and it is a lot about disfavouring there too, with the teacher and so, so I could identify myself in the novel. I have thought a lot about that I would like to contact my primary school teacher again, just to get closure.

[Miriam, 2005 p.61 authors' translation]

She expresses her experiences of exclusion, of not participating, of not being good enough, not being noticed, making mistakes and not understanding the content.

Miriam says:

We had to present to our teachers what the novels were about, but usually I did not tell them anything, so I was seen as not doing my homework. I remember that I said: "I don 't know", though maybe I did. If you are an outsider, you're afraid of being laughed at, whatever you say, and then it will be like you're talking nervously thus ...

[Miriam, 2005 pp. 58-59 authors' translation]

Kate remembers her own reading in school mostly like a reading exercise and she hardly remembers something else about reading but the formalized reading practise in her first years in primary school.

Kate says:

Yes, I remember those short words we had to repeat after the teacher and you have to write letters, large and small, exactly on the line. Yes, it was very important indeed!

[Kate, 2005, p.95 authors' translation]

Eve remembers that they used phonics in first degree and the first letter to learn was O. She thought that was strange because she knew that the alphabet begins with the letter A. She never gets any explanation why the teacher started with $\mathrm{O}$.

Eve says:

We had the alphabet and those old pictures with letters. Old, I don't know, I think they use them still in school. For example, for the letter $O$ there was a snake ('orm' in Swedish) and the picture was placed over the blackboard. I remember this, and as we went through the alphabet and learned the letters, they were placed on the wall over the blackboard. Then we had orthography, and then she read words out 
loud, and then we should write and draw a picture.

[Eve, 2005 p.106 authors' translation]

When the students encountered reading in the school context, something else was expected from them than the reading they had experienced at home. The students talk about experiencing 'challenges' and 'gaps' between the different contexts. In these encounters, they required a confirmation that they still were readers. The methods relating to learning to read and developing reading skills that they encounter at school also differ from the reading they were used to in the family context. They had previously experienced, in their families, that reading was playful and fun. Anne is very fond of reading her novel, however, she was not inspired to read fiction in school. In the early school years, the requirements are experienced as too vague to understand and respond to, and sometimes the teacher attitudes are perceived as insulting and incomprehensible.

\section{Reading in later school years}

Eve talks about having to commit to her teacher's choice of novel and about what she learned from the situation.

Eve says:

We got to read novels, it may have been in the fifth grade or perhaps in sixth grade, the teacher decided what books we should read. I also clearly remember one day when we came into the classroom, on each bench there were novels which we should read and so we had to write something that she said was called a review.

Interviewer:

Did she choose different novels for each one of you?

Eve:

Yes it was different books, she had chosen quite individually after what she thought suited us, and I was so angry at her because she had chosen a novel about Indians for me and I thought that was yuk. I:

Do you remember that you felt angry?

Eve:

Yes! I wanted to change! I didn't want to read that book!

$\mathrm{I}:$

Were you allowed to change?

Eve:

No!

I:

What did she say?

Eve:

No, this suits you, she said. So, I read and it was really exciting! So, she knew what she was doing! [Eve, 2005; interview material authors' translation]

Eve says it was something completely new, "a new kind of adventure to read about!" Now in retrospect, her teacher, who dared to stand up and give each student an individually selected book based on the pupils' reading development, fascinates Eve. In later school years the students talk about reading literature in school.

Eve says:

I remember I read 'The city of my dreams'. This must have been in the later school years, in lower secondary school. It was a story that impressed GREATLY on me. Thus, I think we had a teacher who integrated literature in history teaching.

[Eve, 2005 p.110 authors' translation] 
Anna-Karin SVENSSON. The importance of 'significant others' in bridging the gaps between different reading contexts

$\begin{array}{r}\text { PROBLEMS } \\ \text { OF EDUCATION } \\ \text { IN THE } 21^{\text {st }} \text { CENTURY } \\ \text { Vol. 76, No. 2, } 2018 \\ \hline 242\end{array}$

The integrated way of working with literature and specific subjects is thus enlightened by Eve. Anne talks about her classmates and how the classmates positively affected each other in terms of literary reading. However, she does not seem to be driven by intrinsic motivation when she is talking about reading.

The meeting with the teaching in school means perception of a new identity for Miriam. She does not think she is good enough as a person. She can read, she was even a skilled reader in the early school years, but she feels socially excluded, and it has consequences for her continuing literacy development and learning.

Miriam says:

I felt that it was her way of looking and talking to me, for there were many ... it was both weak and strong students in the class, and I probably was a weak student, not because of my skills, but because of, well I do not know. I think she thought I was annoying in some way. Interviewer:

Why?

Miriam:

I felt that she treated me with a little disgust in some way.

[Miriam, 2005 p.63 authors' translation]

In the example above, it will be made visible that 'significant others' can have both a positive and a negative impact on students, which affects the student's emotional and social development as well as learning.

\section{Reading in secondary school years}

Miriam continues to talk about how she meets an upper secondary school teacher who watches her theatre performance and offers her new opportunities to improve her grades. This encounter leads to a turning point in Miriam's schooling.

Miriam says:

Thus, it was like I became noticed and I have not felt that much before. I have felt that I come from a working-class family and I ... I suppose I'm mediocre, there is no one who believes in me because I was already classified, but then when she said so, that you could see an improvement and everything, so I thought it was obvious, I have the same chance as everyone else. But there are not many teachers who do like this, nothing I've noticed in the other classes during my years before secondary school.

[Miriam, 2005 p.64 authors' translation]

At this turning point, Miriam felt the opportunity to progress from a student who was not capable to a student who wants to do something that has meaning. She accepts the challenge and becomes motivated by the existence of a teacher who believes in her ability.

Anne expresses how hard it is to analyse and interpret poetry. She is challenged during literature lessons in secondary school, where she is expected to analyse and interpret poetry and drama.

Anne says:

Yes, It has been so difficult ... I am a human being talking to people, I tell them what I feel, I'm open. People who write poems are like little more closed, write down what they are feeling ... and so it should rhyme, and so it will be nice, and I think it is. For me it is very difficult to understand those people! Unfortunately, I might need it! I'm really sorry I feel that way. I can say to my buddy, 'Oh, God, what a poem'. But I couldn't interpret poems, in spite of that we had interpreted a lot of texts in school. Very much. When the teacher asked: 'Anne, what is meant by this poem?'I said, 'That they are in love perhaps'. Yes, and so my friend then just interprets the poem wonderfully, she really understands the author's feelings! And I just sit there and shit ... I'm sad that I couldn't do this! At the same time, I must consider it dorky because I really want to like it, but I cannot!

[Anne, 2005 p.81 authors' translation] 
Anne feels confused by the situation and concludes that it is due to her personality that she does not understand these kinds of texts. It seems like she wanted to read and interpret poetry, but she is not comfortable with the genre and therefore chooses to say that she does not understand poetry. Anne seems not to have the necessary significant others who can help bridging the gap between the literary genre she is used to and the new genre in secondary school.

When Kate reads literature in the secondary school she perceived reading novels was like escaping reality for a while.

Kate says:

Maybe it's about being able to identify yourself in a book and maybe escaping a bit from reality for a while, I think. I probably always feel it when I read a book, I can do that today, too. Escape from reality that is just like identifying with the person in the novel.

[Kate, 2005 p.97 authors' translation]

In the later school years, Kate is mostly choosing fiction books. The reading should make her happy, she says. Play, desire and imagination are important aspects even in upper secondary class reading. She says that she was avoiding the 'heavy literature' during these years.

Eve is developing a different type of reading where she wants to be inspired by other readers. She is attracted by friends who read and even their reading parents, because Eve's parents do not read themselves.

Eve says:

Yes, you know, I remember particularly one friend, I remember that her parents had a large bookcase, and I knew that they read a lot. So you knew that you could go there, and I remember that in the particular book 'The city of my dreams', there was someone, a female character who stuck with me and I felt that she reminded me of someone else, but I couldn't think of anyone in any other book. Then I remember that I asked the father in the family if he could help me recognizing the literature person, because I knew that he read many books. But this was such an episode I remember, it was like another 'source to get'.

[Eve, 2005 p.111 authors' translation]

Eve believes that this was important for her development to become a reader in a life perspective. The teacher, friends and friends' parents become the significant others.

\section{Reading in teacher education}

In the encounter with reading at the school of teacher education, both confirmation and participation stand out as significant aspects.

Receiving confirmation and recognition mainly takes place in the seminar groups. These are essential for students to feel that they receive support and confirmation through conversations and discussions concerning different texts and experiences. This support leads to participation, development and learning. Nevertheless, the students express the desire to get feedback and confirmation from the teacher, and that to a greater extent is the case. They talk about a feeling of insecurity, which is about adapting, 'doing the right thing', and the need of external motivation for their studies.

Kate says:

I think it has been actually bad! On that level also ... At least the response or feedback, or it's the same. I'm still waiting for feedback on my latest assignment. I haven't heard anything about it. At least I would like to have it confirmed, that the teacher has read it, that she will be back or so ... That I think is a shame!

[Kate, 2005 p.139 authors' translation] 
PROBLEMS

OF EDUCATION

IN THE $21^{\text {st }}$ CENTURY Vol. 76 , No. 2, 2018

When the students encounter 'new challenges' in a new context, these challenges may lead to a feeling of gaps between earlier experiences of reading and the new ones. In a similar manner, the students' earlier reading trajectories indicate that there have been gaps between different levels of education. Bridging the gap between different educational contexts is a challenge for both students and teacher educators.

Becoming conscious of 'an interest in the text' is important for the students' reading, and they emphasize that the most interesting point is when theory and practice are connected. The texts become meaningful first when the students know how they are going to use them. Based on the students' stories, it also appears that they would like to read more fiction. However, the students' literary reading is not challenged to cross genres. Instead, reading becomes an activity of emotional confirmation. Thus, the students need more discussions about literary texts on various genres.

Eve says:

Actually, there hasn't been so many discussions and that's a problem. It's a pity that the literature hasn't been discussed so much, not directly the books.

[Eve, 2005 p.143 authors' translation]

Through 'new ways of reading', the student both wants to gain new thoughts, and to get a confirmation for what he/she already believes. The main task for the supervisor is thus to be open, listening and supportive in the group, but also to dare to be challenging and unsettling.

Group work is directed towards shared goals, but the students lack a scope of action to influence content and contribute with their own background knowledge. There is some uncertainty concerning the students' own cultural capital, which they bring with them into the new educational context, and how this capital can be adapted to the culture of the university.

Kate says:

If you think about the first semester than you haven't got the experience, then you just read and you don't think in that way, but now when we have talked to each other and when we have discussed and so on ... eh ... yes then you are reflecting and reading and could see what is important. And you could see there is repeat all the time.

[Kate, 2005 p.137 authors' translation]

Kate believes that these repetitive thoughts are different examples of the same thoughts and that they will help her in new ways of reading. There are different ways to express oneself, to clarify and establish knowledge. This becomes clear through conversations and discussions during the training.

Miriam says:

It is so incredibly important that you have a dialogue (with the teachers) and that you feel safe and that there exist no stupid questions, because this is what we will convey to our students in the future.

[Miriam, 2005 p.124 authors' translation]

The students' personal experiences and memories, from working with reading and writing during their own school years, are latent. These memories resurface, in connection with the instruction they get in this field within the teacher education program, as well as in their meetings with pupils in the reading and writing practice of compulsory school. The students feel that teaching pupils to read and write is something very special, which demands a specific teacher competence and particular methods of learning.

Anne says:

We must feel that we are doing well. We must feel that 'Anne you will be a good teacher, we believe in you'. You sometimes feel that you are worthless because you couldn't write a text!

[Anne, 2005 p.134 authors' translation] 
The pre-service teachers also talk about their anxiety, with respect to the teacher ideals that are presented in the frame of teacher education. Such anxieties may involve, for instance, not being able to provide all pupils with opportunities to achieve goals, with respect to the syllabus goals. The students wish to become competent teachers, who fulfil the demands placed on them by the teaching mission, as stipulated through governing documents.

\section{Discussion}

The pre-service teachers' reading trajectories reveal that the need for significant others who support the reading process exists and persists. Significant others play an important role in all the contexts mentioned by the students, ranging from early reading when they were toddlers, to the reading as adults, in various practices of reading. These various practices of reading can be seen as communities of practice (Arthur, 2016; Lave \& Wenger, 1991; Wenger, 1998). Here comparisons can be made with the concept of 'literary breastfeeding' (Crafoord, 1991 p.26) and socialization into new text worlds (Dyson 1997; Cochran-Smith 1994; Heath, 1983, 2001). The metaphor 'literary breast-feeding' shows how interest in reading is transmitted in a close relationship to a significant other, which then leads onwards to the child learning to read him/herself. 'Literary breast-feeding' compares to being socialized into different reading practices and appears to be increasingly important in all contexts the students participate in. It is making the child/pupil/student positive to reading and giving him/her a feeling of participation in different 'literacy clubs' (Smith, 2012, p. 229). Such membership appears to have different meanings in different contexts.

The students' reading trajectories show that 'artefacts' of various types are crucial and basic conditions for raising interest in texts. Artefacts are used as tools to shape 'play, motivation and imagination'. For early reading in a family context, the artefacts may consist of, for instance, toys, different kinds of texts, and TV and movies. The artefacts mediate reading, through the games and activities they stimulate (Vygotsky, 1998, 2012; Wertsch, 1998). It's important that teachers are aware of that the education system does not offer the same conditions and opportunities for learning to all students, which means that education needs to be adapted to facilitate learning. Teachers therefore need to have deep knowledge in reading on different levels and in different practices and knowledge how to use many diverse mediating tools and methods as complements in challenging students in their learning.

The result clearly shows the importance of 'significant others' who support the relational reading process. In contrast, the lack of 'significant others' leads to uninterest in reading (Applegate \& Applegate, 2004, 2014). It is important that pre-service teachers and, of course, teachers at all levels themselves have an interest in reading and realising what creates interest in reading and reading comprehension in different genres at different levels and in different situations in life.

The result can also be compared with Brooks (2007) results pointing at the importance of knowing how to support their students as readers and writers and being aware of the teachers' insufficient literacy skills. The teacher needs both an own interest in reading and deep knowledge in how to support the pupils/students. Hall (2005) and Warren-Kring and Warren (2013) found that simply creating positive attitudes towards teaching reading was not enough. Teachers need knowledge about how to teach reading both specifically to the subject and to how the students need to be taught. From a socio-cultural perspective, teachers also need to know the students' written-language experiences in order to bridge the gap between different reading practices and stages in school. The students' reading trajectories show that several societies of readers exist simultaneously, in each of the different contexts they describe. These different 'literacy clubs' could be compared with literacies in plural (Gee, 2015; Lea \& Street, 2006; Street, 2014). Literacy needs to be seen as literacies, where written-language practices are used for different purposes and contexts depending on content and what they can be used for in action (Gee, 2015; Lea \& Street, 1998, 2006: van Enk, Dagenais, \& Toohey, 2005). 
PROBLEMS

OF EDUCATION

IN THE $22^{\text {st }}$ CENTURY Vol. 76, No. 2, 2018

246

The gaps between different practices of reading along the reading trajectories show that the students experienced new challenges in each new context. The result indicates that it seems important that teachers at different levels in school must cooperate on pupil/students' reading in different contexts and for different subjects. A convenient way to bridge the gaps in reading trajectories is to create temporary supportive structures, scaffolding, which means to really meet the child/pupil/student in a relational perspective within their proximate development zone (Vygotsky, 1978, 2012). Leese (2010) points out in her study that new students need to be supported in transitions into higher education. She stressed that the teaching staff must be aware of the importance 'to consider the barriers of learning' (p. 248). In order to meet the child/pupil/ student as a participating member of the various societies of readers, the teacher needs a living interest in pupil/students' experiences of reading and how to motivate reading in a life-long perspective.

The students in this research are well aware of that they are becoming teachers in the future and taking the role of 'significant others', who will contribute to the pupils'/students' socialization to literacy in diverse contexts and for different purposes. The students who participated belong to two generations, but no significant differences 'between the generations in their reading trajectories' from reading in school were revealed. Their narratives show large similarities with regard to early reading, pointing to a collective narrative about how to teach and learn reading conducted in the early school years. It is also interesting to consider whether these experiences of traditional ways of teaching and learning reading will be something, they will bring as new teachers, although the education advocates other methods related to new needs in contemporary school contexts. These are issues that also previous research highlights (Leland, 2013; Toll, Nierstheimer, Lenski, \& Kolloff, 2004; Zeicher, 1999). It has been shown that teachers' experiences and attitudes to reading are important for their students reading development. Brooks (2007) points out the importance of teachers developing a belief in their own ability and personal strategies for how to interact with the students and support them in different learning situations. Leland (2013, p. 69) stressed that the teacher education programs must be more explicit to help pre-service teachers to understand changes occurring in contemporary classrooms. She stressed that 'pre-service teachers' literacy histories that contradict the goals of current research on teaching and learning must be addressed'. Leland refers to Zeichner (1996), who is pointing out the importance of teacher education programs focusing on pre-service teachers' capabilities to analyse and evaluate their personal stories of teaching and learning.

All the participating students in this research share the belief, which they carry with them into their teacher training, that specific knowledge exists which is important and necessary, related to 'doing the right thing' and having 'acceptable ways of thinking'. Such notions also apply to the issue of how to teach reading skills. It is important that it 'turns out right'. Problems arise when no coherent 'correct method' is presented in their teacher education. The pedagogical and didactic competence they are supposed to acquire is perceived as unclear and 'fuzzy'. This brings the risk that only the students' personal reading experiences will constitute the educational models in the mission that they are embarking on. Benevides and Stagg Peterson (2010) show in their study that pre-service teachers who have positive experiences of reading from previous contexts can use their reading habits and literacy skills to choose apprehensive reading strategies in their classrooms. This leads to a question in which way teacher education is able to develop all prospective teachers' opportunities for positive attitudes, habits and achievements for teaching their pupil/students.

The positive experiences of significant others are something the students wish to bring with them in their future in collaboration with their pupils' parents concerning learning development, which is accentuated also by Nathanson, Pruslow and Levitts (2008) and Applegate and Applegate $(2004,2014)$. In the narratives in this study, the students explain that their own interest in reading is contagious and rubs off on the children. Becoming aware of their own reading in a life perspective may thus involve insights that reading is a relational process, 
which takes place in situated practices like communities of practice (Arthur, 2016; Lave \& Wenger, 1991; Wenger, 1998). These practices are linked to personal, historical, cultural and social contexts, which means that teaching about reading processes is a much more complicated process than simply teaching how text is decoded, as an isolated skill (Gee, 2008; Lemke, 1990, 1995; Street, 1995). The students' reading trajectories reveal a need for teachers' insights and knowledge how to bridge the gaps that arise between different reading practices in different contexts from pre-school to higher education.

\section{Conclusions and Implications}

The results of this research point out that reading is a relational process and that the most important aspect for the process is 'significant others', who seem to invite, confirm and challenge the reader in every reading context in a life-long-perspective. From a school perspective, the pre-service teachers' reading trajectories reveal a need for teachers' insights and knowledge on how to bridge the gaps that arise between school contexts from pre-school to higher education. This suggests that teachers need to be aware of their pupils'students' reading development as well as having knowledge about how to improve their reading in a life-long perspective. This would require a need for teacher cooperation over the school context borders.

Further research should explore to which extent it is feasible for teachers in different school contexts, from preschool to higher education, to take a relational perspective on reading and literacy, and if and how it's possible to bridge the gaps between these contexts. Another relevant research question is how teacher education can develop all prospective teachers' opportunities for positive attitudes, habits and achievements regarding their own reading, along with pedagogic/didactic knowledge of how to teach students to become readers and remain readers in a life-long perspective.

\section{References}

Applegate, A. J., \& Applegate, M. D. (2004). The Peter Effect: Reading habits and attitudes of preservice teachers. The Reading Teacher, 57 (6), 554-563.

Applegate, A. J., Applegate, M. D., Mercantini, M. A., McGeehan, C. M., Cobb, J. B., DeBoy, J. R. \& Lewinski, K. E. (2014). The Peter effect revisited: Reading habits and attitudes of college students. Literacy Research and Instruction, 53 (3), 188-204.

Arthur, L. (2016). Communities of practice in higher education: Professional learning in an academic career. International Journal for Academic Development, 21 (3), 230-241.

Benevides, T., \& Peterson, S. S. (2010). Literacy attitudes, habits and achievements of future teachers. Journal of Education for Teaching, 36 (3), 291-302.

Bergman, L. (2016). Supporting academic literacies: university teachers in collaboration for change. Teaching in Higher Education, 21 (5), 516-531.

Biggs, J. B. (2011). Teaching for quality learning at university: What the student does. McGraw-Hill Education (UK).

Blåsjö, M. (2004). Students' Writing in Two Knowledge-constructing Settings. (Doctoral thesis, Acta Universitatis Stockholmiensis).

Brooks, G. W. (2007). Teachers as readers and writers and as teachers of reading and writing. The Journal of Educational Research, 100 (3), 177-191.

Brockmeier, J. \& Carbaugh, D. (2001). Introduktion. In J. Brockmeier \& D. Carbaugh (Eds.), Narrative and Identity (pp.1-22). Amsterdam: John Benjamins Publishing Company.

Bruner, J.S. (1990). Acts of meaning. Cambridge, MA: Harvard University Press.

Bruner, J.S. 2001: Self-making and worldmaking. In J. Brockmeier \& D. Carbaugh (Eds.), Narrative and Identity (pp.1-22). Amsterdam: John Benjamin's Publishing Company

Cochran-Smith, M. (1984). The making of a reader. Norwood: Ablex.

Crafoord, C. (1991). Daddy's body. In C. J. De Geer (Eds.), Daddy and me: Fourteen men tales (pp. 2343). Stockholm: Sesam.

Dyson, H. A. (1997) Writing superheroes. Contemporary childhood: Popular culture, and classroom literacy. New York: Teachers College Press

\begin{tabular}{|l} 
PROBLEMS \\
OF EDUCATION \\
IN THE 21 $1^{\text {st }}$ CENTURY \\
Vol. 76, No. 2,2018 \\
\hline 247
\end{tabular} 
Anna-Karin SVENSSON. The importance of 'significant others' in bridging the gaps between different reading contexts

\section{PROBLEMS \\ OF EDUCATION \\ IN THE $21^{\text {st }}$ CENTURY Vol. 76, No. 2, 2018 \\ 248}

Gee, J. (2015). Social linguistics and literacies: Ideology in discourses. London: Routledge.

Goodson, I. \& Numan, U. (2003). Life history and professional development: Stories on teachers' life and work. Lund: Studentlitteratur.

Goodson, I. \& Sikes, P. (2001). Life history research in educational settings: Learning from lives. Buckingham: Open University Press.

Haggis, T. (2006). Pedagogies for diversity: Retaining critical challenge amidst fears of 'dumbing down'. Studies in Higher Education 31 (5), 521-35.

Heath, B. S. (1983). Ways with Words: Language, life and work in communities and classrooms. Cambridge: Cambridge Univ. Press.

Heath, B. S. (2001). What no bedtime stories means: Narrative skills at home and school. In A. Duranti (Ed.), Linguistic anthropology: A reader (pp. 318-343). Boston: Blackwell Publisher.

Heath, S. B., \& Street, B. V. (2008). On ethnography: Approaches to language and literacy research. New York: Teachers College Press.

Lave, J., \& Wenger, E. (1991). Situated learning: Legitimate peripheral participation. Cambridge: Cambridge Univ. Press.

Leland, K. M. (2013). The impact of a teacher preparation literacy course on pre-service teachers' perceptions of teaching young children how to read. SRATE Journal, 22 (2), 65-70.

Lea, M. R., \& Street, B. V. (1998). Student writing in higher education: An academic literacies approach. Studies in Higher Education, 23 (2), 157-172.

Lea, M. R., \& Street, B. V. (2006). The "academic literacies" model: Theory and applications. Theory into Practice, 45 (4), 368-377.

Leese, M. (2010). Bridging the gap: Supporting student transitions into higher education. Journal of Further and Higher Education, 34 (2), 239-251.

Lemke, J. L. (1990). Talking science: Language, learning, and values. Norwood: Ablex.

Lemke, J. L. (1995). Textual politics: Discourse and social dynamics. London: Taylor \& Francis.

Leathwood, C., \& O'Connell, P. (2003). 'It's a struggle': the construction of the 'new student' in higher education. Journal of Education Policy, 18 (6), 597-615.

Lincoln, Y. S., \& Guba, E. G. (1985). Naturalistic inquiry. Beverly Hills, CA: Sage.

Nathanson, S., Pruslow, J., \& Levitt, R. (2008). The reading habits and literacy attitudes of in-service and prospective teachers: Results of a questionnaire survey. Journal of Teacher Education, 59 (4), 313-321.

Polkinghorne, D. (1995). Narrative configuration in qualitative analysis. In: J.A. Hatch \& R. Wisniewiski (Eds.), Life history and narrative (pp. 5-23). London: Farmer Press.

Smith, F. (2012). Understanding reading: A psycholinguistic analysis of reading and learning to read. Routledge.

Statistiska centralbyrån, statistics Sweden [SCB], 2016. Retrieved September 1, 2017, from http://www. scb.se.

Street, B. V. (2014). Social literacies: Critical approaches to literacy in development, ethnography and education. Routledge.

Svensson (2011). Pre-service teachers' narratives on reading: From early childhood to the encounter of teacher education. (Doctoral thesis. Malmö University).

The Swedish Research Council. Research - ethical principles in humanities-social science research (2002). Retrieved March 26, 2018 https:/www.vr.se/inenglish/researchfunding/applyforgrants/ conditionsforapplicationsandgrants/ethicalguidelines.4.5adac704126af4b4be280007769.html

Toll, C. A., Nierstheimer, S. L., Lenski, S. D., \& Kolloff, P. B. (2004). Washing our students clean: Internal conflicts in response to preservice teachers' beliefs and practices. Journal of Teacher Education, 55 (2), 164-176.

University and Higher Education Council, 2014. Retrieved September 1, 2017, from https://www.uhr.se/ globalassets/_uhr.se/publikationer/2016/uhr-kan-excellens-uppnas-i-homogena-studentgrupper. pdf.

Vygotsky, L. S. (1978). Mind in society. The development of higher psychological process. USA: Harvard University Psychological Press.

Vygotsky, L. S. (2012). Thought and language. MIT press.

Wenger, E. (1998). Communities of practice: Learning, meaning, and identity. Cambridge: Cambridge University Press.

Wertsch, J. V. (1998). Mind as action. New York: Oxford University Press. 
Zeichner, K. (1996). Designing educative practicum experiences for prospective teachers. In M. L. Gomez, S. Melnick, \& Zeichner, K. (Eds.), Currents of reform in preservice teacher education (pp.215-234). New York, NY: Teachers College Press.

Zepke, N., \& Leach, L. (2007). Improving student outcomes in higher education: New Zealand teachers' views on teaching students from diverse backgrounds. Teaching in Higher Education, 12 (5-6), 655-668.

Zepke, N., \& Leach, L. (2010). Improving student engagement: Ten proposals for action. Active learning in higher education, 11 (3), 167-177.

Received: February 21, 2018

Accepted: April 10, 2018

\section{Anna-Karin Svensson}

